\title{
Effect of Micro-Agricultural Financial
} (1) consenath Institutions of South Africa financial services on livelihood capital of beneficiaries in North West Province South Africa

\author{
Idowu Oladele* and Lucky Ward
}

\begin{abstract}
Background: This paper examined the effect of Micro-Agricultural Financial Institutions of South Africa financial services on livelihood capital of beneficiaries in North West Province South Africa. A simple random sampling technique was used to select 280 respondents from a total of 344 beneficiaries. A structured questionnaire was used to collect data from November 2015 to March 2016, which was analysed using the Statistical Package for Social Sciences (SPSS) with frequencies, percentages and Wilcoxon signed-rank test.
\end{abstract}

Results: The results of the study show that there has been a significant change on livelihood assets after MAFISA support. The proportion of access and ownership of livelihood assets increased for most of the indicators of the assets by at least $90 \%$ after MAFISA support. Wilcoxon signed-rank test results revealed that access to financial capital from banks improved substantially $(Z$ scores $=15.556 ; p$ value $=0.000)$ and cooperatives $(Z$ score $=-11.305 ; p$ value $=0.000)$. Respondents are now able to associate and form some networks with others ( $Z$ score $=-15.875 ; p$ value $=0.000)$, network with government $(Z$ score $=-15.811 ; p$ value $=0.000)$ and network with the private sector (Z score $=-15.363 ; p$ value $=0.000)$.

Conclusions: The study concludes that access to microfinance leads to significant changes in financial, social, natural, human, physical and social livelihood assets after MAFISA support. The proportion of access and ownership of livelihood assets increased for most of the indicators of the assets by at least $90 \%$ after MAFISA support. Statistical significant differences confirmed the changes in the proportion of beneficiaries before and after MAFISA support such as access to financial capital from banks improved substantially and cooperatives, networking with others, network with government and network with the private sector as well as increasing their skills and competencies as well as their physical asset accumulation.

Keywords: Microfinance, Livelihood, Assets, Wilcoxon signed-rank test, Financial support

\section{Background}

Micro-Agricultural Finance Institutions of South Africa (MAFISA) was established by government in 2004 with a view to facilitate the provision of equitable access to financial services by economically active rural communities [1]. MAFISA's policy is to empower micro-level

*Correspondence: oladele20002001@yahoo.com

Department of Agricultural Economics and Extension, North West

University Mafikeng Campus, Mmabatho 2735, South Africa producers, processors, micro-entrepreneurs and small producers. The policy states that applicants must demonstrate the willingness and ability to repay and possess clean credit record. Loans of up to R 500,000.00 are offered by the scheme, and the amount may be increased after valid justifications. Collateral is only required for loans above $R$ 25,000.00, and repayments are aligned with the cycle of the enterprise. Funds are transferred directly into the supplier's bank account and not that of the applicant to ensure that people do not use the capital 
for unintended purposes but on agriculture, forestry and fisheries sector to improve their livelihoods.

A livelihood framework was used to measure the impact of MAFISA financial services on beneficiaries' livelihood, with special focus on their capital. Livelihood framework examines the complexity of livelihood, especially the poor. The impact of financial capital, physical capital, human capital, social capital and natural capital of respondents was assessed to ascertain the overall impact on the likelihood of respondents. According to [1], access to microfinance is not in itself sufficient to ensure desired positive impact on the livelihood of clients rather the combination of livelihood assets. According to [2], financial capital is the most important ingredient in establishing a sustainable business that generates good income. According to [3], access to financial capital to acquire fixed assets is important for any business to have a competitive advantage and sustain its operations. Handa et al. [4] assert that microfinance has positive impact on clients as assets increased after association with an intervention measure.

According to [5], social capital is used to generate services that enhance the output realised from other inputs without being used up in the process of production. It is through social capital that people and institutions can pool their resources to achieve goals, which are not individually attainable. Goodwin [2] argues that human capital is investment in people to develop skills, competence and capabilities to be more productive and that natural capital are natural resources needed by firms to produce products. Livelihood outcomes emanate from livelihood strategies and assets such that strategies are comprised of a range and combination of activities and choices that people undertake for them to achieve their livelihood outcomes [6-8]. Bhuiyan [9] defined sustainable livelihood framework as a process that organises various factors to enhance livelihood opportunities for households. Microfinance plays a major role in improving the livelihoods of individuals and households in countries where poverty is rampant [10]. Microfinance is generally considered as a crucial tool used to improve people's livelihoods.

Micro-credit has been reported to have a positive and significant impact on the growth of small and medium enterprises and welfare of poor households [11, 12]. According to [13], microfinance has over the years been the most effective tool used against global poverty. Sebstad and Chen [14] further state that the impacts of microfinance on income and profits are generally positive. Mula and Sarker [15] revealed that women in China, who had access to microfinance, witnessed a significant increase in annual income and savings compared to those who did not; their assets and investments increased, thus leading to the creation of more employment opportunities.

Kgowedi [16] stated that most financial institutions do not invest their resources and lack of infrastructure in rural areas due to high risk and transactional costs. In South Africa, the drive to increase access to affordable banking also has a political context. Since 1994, economic empowerment has been at the heart of the transformation of the South African society. The introduction of the Banks Act (94 of 1990) led to a phenomenal growth in the industry with the issuing of new banking licences. Smallholder farmers, due to their peculiar characteristics, constitute a very large part of customer base of microfinance institutions in South Africa but are often neglected due to costly transactions and high risks. Lohlein and Wehrheim [17] point out that agriculture and rural development can be fostered through the provision of rural credit because it is a powerful tool to generate successful smallholder farmers and sustainable businesses. Wrenn [18] argues that microfinance institutions must go beyond analysing quantitative data and loan sizes to understanding the impact of these projects on the livelihoods of clients. The research question that emanated for this study is whether there are differences in the acquisition of livelihood assets after intervention by microfinance services, while the main objective of the study was to assess the impact of MAFISA services on the livelihood capital of beneficiaries in the North West Province. The significant differences in the acquisition of livelihood assets before and after MAFISA services were also explored as hypotheses.

\section{Methods}

The study was carried out from November 2015 to March 2016 in all four district municipalities of the North West Province (NWP), namely Bojanala Platinum District, Ngaka Modiri-Molema (Central) District, Dr Kenneth Kaunda (Southern) District and Dr Ruth Segomotsi Mompati District. The North West is the fourth largest Province in South Africa, with a land size of 104,882 square kilometres representing 8.7 per cent of the country's total surface area. Agriculture is the second biggest contributor to the Provincial Gross Domestic Product (GDP) after mining. Summer temperatures range from 17 to $31^{\circ} \mathrm{C}$, and the total annual rainfall is about $360 \mathrm{~mm}$.

The population of the study consisted of all smallholder farmers supported by MAFISA in the North West Province. Males and females, including the youth who borrowed capital from the institution to establish new enterprises and expand existing ones, constituted the population of the study. These enterprises were maize, vegetable, sunflower and beef cattle. There are 344 beneficiaries of MAFISA in the province. Simple random sampling was used to select participants for the study. 
This was performed throughout the province, and all beneficiaries supported by MAFISA stood equal chances of being selected. A sample size of 280 farmers was randomly selected from the various districts of the Province. The targeted sample size of 280 respondents was dropped to 273 after some incomplete questionnaires were discarded. The sample size of 280 farmers was arrived at using the Raosoft Sampling Technique based on 5\% error margin. Respondents consented voluntarily to respond to questions posed to them by enumerators. All respondents were advised not to participate in the study if they felt uncomfortable. The purpose of the study and the need to participate in the study were adequately explained to every respondent.

Completed questionnaires were coded, captured and analysed using version 21 of the Statistical Package for Social Sciences (SPSS). Descriptive statistics, frequencies, percentages, graphs and charts were used to summarise the data. Wilcoxon test was used to assess the livelihood capital (financial, physical, human, social and natural) of respondents before and after they received MAFISA support. In this study, indicators were developed for livelihood asset, which were rated by respondents on a 2-point scale of high and low for each of the indicators before and after MAFISA intervention. The Wilcoxon signed-rank test applies to two-sample designs involving repeated measures, matched pairs, or "before" and "after" measures like the $t$ test for correlated samples. The Wilcoxon signed-rank sum test is used for ordered categorical data where a numerical scale is inappropriate but where it is possible to rank the observations and to test null hypothesis that the median of a distribution is equal to some value [19]. The Wilcoxon signed-rank sum test is a nonparametric version of a paired-sample $t$ test. This test is used if a researcher does not wish to assume that the difference between the two variables is interval or normally distributed (but assumes the difference is ordinal). Wilcoxon signed-rank test is $W$, defined as the sum of the positive ranks $(W+)$ and sum of the negative ranks $(W-)$. For a true null hypothesis, there is equal number of both positive and negative; however, the higher number of positive ranks than negative ranks connotes that the research hypothesis is true [20]. The test is robust and highly efficient for moderate- to heavy-tailed underlying distributions. In particular, it is a real improvement over the sign test and is almost fully efficient when the underlying distribution is normal. Wilcoxon signed-rank statistics can be computed as a sign statistic of the pairwise averages of data [19]. A mathematical explanation of the Wilcoxon signed-rank test for the study is as follows:

$$
W=\sum_{i=1}^{N r}\left[\operatorname{sgn}\left(x_{2, i}-x_{1, i}\right) R_{i}\right]
$$

where $W=$ Wilcoxon signed-rank test; $N_{r}=$ sample size, $X_{12}=$ measuring levels; for $I=1,2, \ldots, n ; X_{1}\left(\mathrm{~F}_{1}, \mathrm{P}_{1}, \mathrm{~S}_{1}\right.$, $\left.\mathrm{H}_{1}, \mathrm{~N}_{1}\right)$, "before the project"; $X_{2}\left(\mathrm{~F}_{2}, \mathrm{P}_{2}, \mathrm{~S}_{2}, \mathrm{H}_{2}, \mathrm{~N}_{2}\right)$, "after the project"; $R_{i}$, rank; with $F$, financial capital; $P$, physical capital; $S$, social capital; $H$, human capital; $N$, natural capital.

\section{Results and discussion}

Figure 1 presents the results of access to financial capital by beneficiaries before and after MAFISA support by respondents. The indicators for financial capital show that access and capacity of respondents to government subsidies, Government grant, Income generated, Personal savings and Business investments increased by at least $90 \%$, while personal loans taken and loan shark services decreased by at least $95 \%$ after MAFISA support. Wrenn [18] reported that in Kenya, Uganda and Rwanda, the impact of microfinance is underestimated by impact studies which disregard the possible positive externalities on spheres beyond households. Crepon et al. [21] further maintain that microfinance does not only have a positive impact on borrowers, but also on family members. Duvendack and Palmer-Jones [22] point out that microfinance had a positive impact of the livelihoods of beneficiaries.

The results on access to natural capital by beneficiaries before and after MAFISA are presented in Fig. 1. All the indicators used for operationalisation of natural capital show an increasing trend of more than $90 \%$ after MAFISA support. According to [23], microfinance allows income diversification, which reduces risk of loss and, therefore, has beneficial effects on environment. Murali [24] stated that linking micro-credits to various activities under natural resource management by self-help groups has provided gainful employment and income to needy people and their participation in conservation and regeneration of resources. Diro and Regasa [25] indicated that natural capital plays an important role in improving the livelihoods of clients through increased income and assets.

Figure 1 shows the findings on access to social capital by beneficiaries before and after MAFISA support. All the indicators for social capital show an increasing trend of more than $90 \%$ after MAFISA support. Khatun and Hasan [26] assert that bonding, bridging, norms and reciprocity are easy to use in the function of microfinance that can contribute to reduce poverty and create social capital. World Bank [27] indicated that there is strong relationship between social capital and microfinance such that group lending method creates bonding among the group members prior to receive micro-loan such that group lending mobilises resources and facilitates easy access of the poor to credit market that creates social 


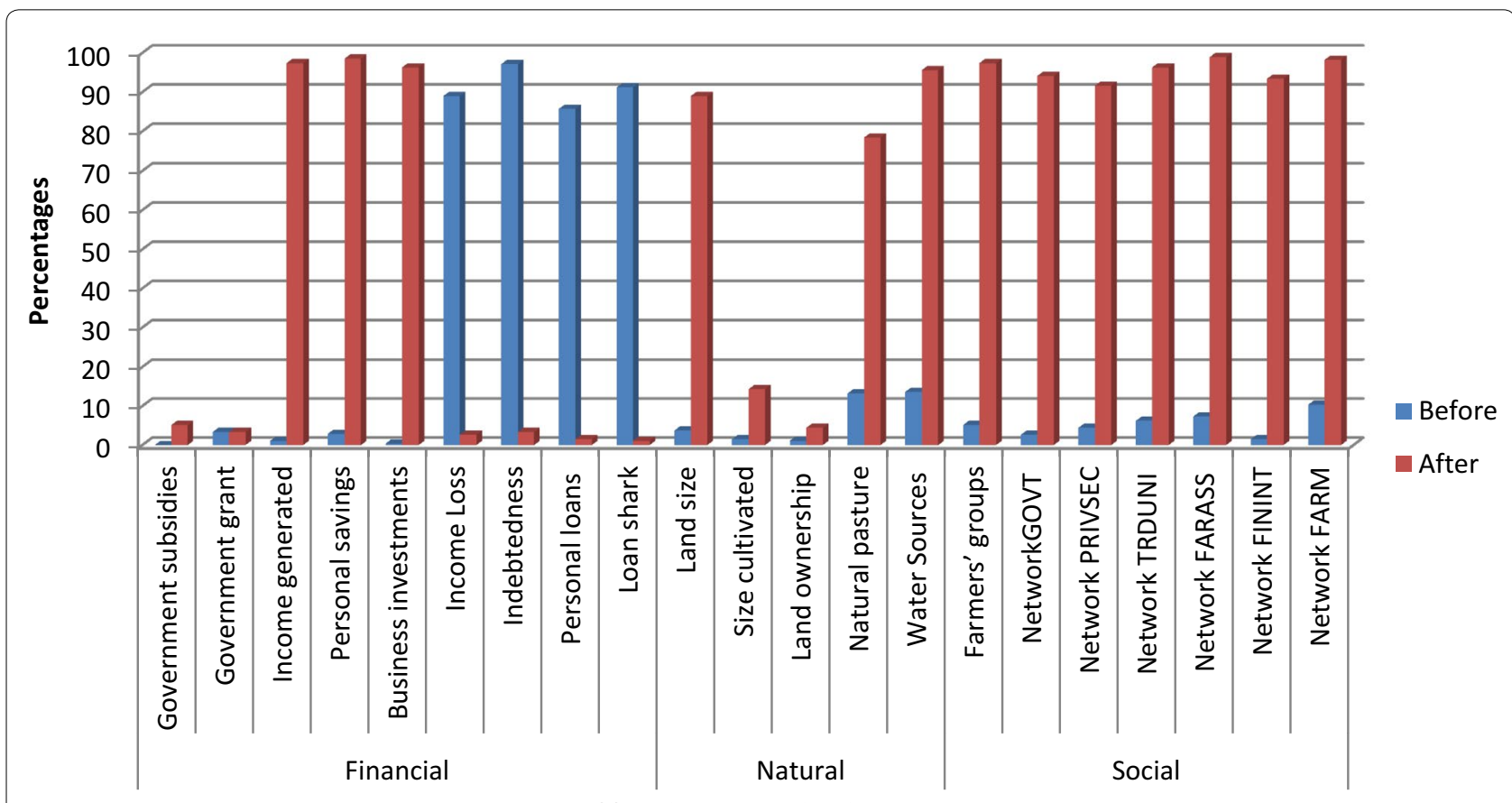

Livelihood assets and indicators

Fig. 1 Percentage distribution of respondents according to indicators for financial, natural and social assets before and after MAFISA services

well-being as well as social capital. Khatun and Hasan [26] reported that Micro Bank helps to increase the income of the poor that impacts positively to raise their standard of living as well as social capital through capacity building and networking. Ameen and Sulaiman [28] reported that microfinance has had significant impact in Bangladesh because microfinance creates social capital that has generated greater economic well-being. Molyneux [29] argues that microfinance diminishes the existing level of positive social capital by creating a socially corrosive competitive individualism; however, socially corrosive competitive individualism can be abated in the field of microfinance through networking.

Khatun and Hasan [26] argue that Micro Bank microfinance connects the marginalised people who are the members' same association through lobbing and networking that create social capital. Makina and Malobola [30] found a positive impact on the livelihoods of beneficiaries of microfinance, including women in rural areas where there is not much development taking place. Krueger and Lindahl [31] list four strong institutional operations through microfinance that help strong cooperation among members. They are relations of trust; reciprocity and exchange; common rules, norms and sanctions; and connectedness, networks and groups. Makina and Maloba [30] observed that lower-income households benefited less than those that are not so poor. This observation, they maintain, is consistent with the findings of other studies on similar impact assessments. They also observed that if certain groups such as women are not targeted, men tend to benefit far more than women. Enisan and Olowafemi [32] conducted a study in Ondo State, Nigeria, and found that the provision of credit had a significant and positive impact on the welfare of beneficiaries.

Figure 2 presents the results on access to physical capital by beneficiaries before and after MAFISA support. There is a general trend of increase in access and ownership of physical assets by at least $90 \%$ after MAFISA except for road and market infrastructure. This exception may be, because these physical assets are not exclusive or peculiar to MAFISA's beneficiaries alone. Gubert and Roubaud [33] stated that microfinance loans beneficiaries in Madagascar improved their number of workers employed, received a higher turnover, more physical capital than non-beneficiaries. Anderson et al. [34] stated that microfinance to poor allows them to undertake micro-enterprises to increase resource capital and ownership. Ramakrishnappa and Rao [35] reported the introduction of various microfinance schemes to assist and enhance the capability of the economically weaker people has brought positive and significant results such that the impact of microfinance on dairy has made India the largest producer of milk in the world.

Adjei [36] asserts that through participation in microfinance programme, clients diversified and accumulated 


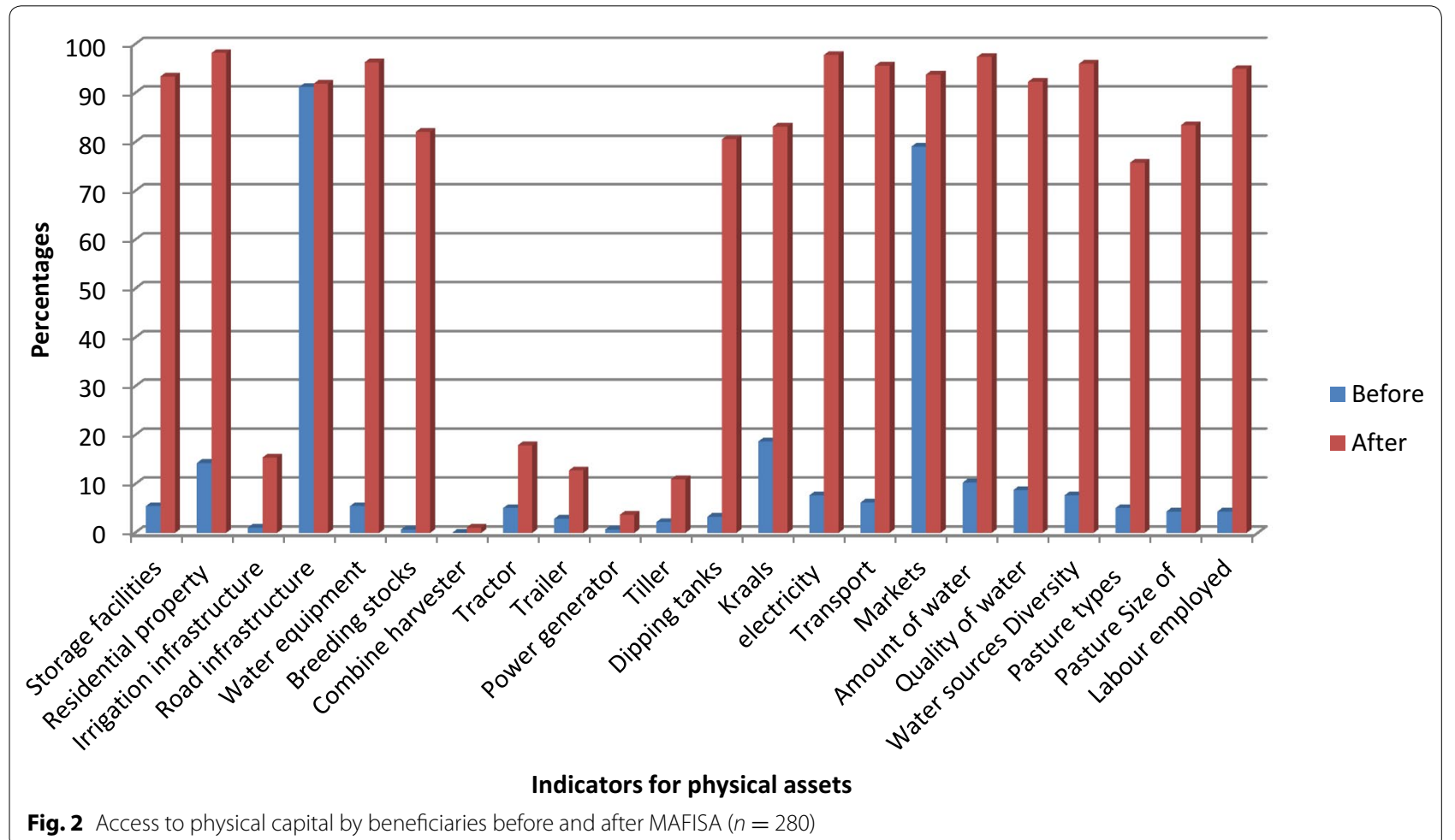

various assets in the form of financial, human and physical capital, and thus, participation in the programme significantly improved clients' living standards through asset accumulation. Odell [37] indicated that microfinance facilities have improved beneficiaries' access to socio-economic facilities such as health, nutrition and education through increased incomes. Enisan and Oluwafemi [32] revealed that credit had a positive impact on poverty and changed the livelihoods of households for the better. Access to credit leads to self-reliance, creates employment and makes individuals to be more dependent on themselves, thus creating a conducive environment for the empowerment of others who do not have access to such credit services. Planet Finance [38] stated that in Egypt microfinance had a positive impact on enterprise development and that it serves as the only external source of finance so direly needed by the poor. Gebru and Paul [39] found in Jimma town, west of Ethiopia, that microfinance had a positive impact on their standard of living and that women have more access to microfinance than men.

The findings on access to human capital by beneficiaries before and after MAFISA support are presented in Table 4. All the indicators used for operationalisation of human capital show an increasing trend of more than 90\% after MAFISA support. Krueger and Lindahl [31] observed that human capital development is a prerequisite for reducing poverty in the long run and occupies the prime place in production because without it other factors of production would not be developed. Antoh et al. [40] indicate that microfinance services enable beneficiaries to expand their human capital assets and that microfinance services included education programmes that added up to enhancing beneficiaries outlook regarding the non-financial aspect of poverty reduction through awareness creation and sensitisation workshops. Adjei et al. [36] contend that the overgeneralisation hinders evidence on microfinance effects on human capital development, thereby leading to the generally weak and inadequate research in human capital. Ferka [6] confirms the general assertion by many researchers that microfinance has a positive impact on the welfare of households that borrow from microfinance institutions.

Table 1 shows the result of the differences in the indicators on financial capital before and after MAFISA support using the Wilcoxon signed-rank test. This was because indicators on financial capital were measured on ordinal scale of high and low for before and after MAFISA support to beneficiaries, respectively. From 14 financial indicators tested, 13 indicators showed significant difference while one did not. These are: access to banks $(Z=-15.56)$; access to cooperative $(Z=-11.305)$; relatives $(Z=-15.558)$; 
Table 1 Access to human capital by beneficiaries before and after MAFISA support $(n=280)$

\begin{tabular}{|c|c|c|c|c|}
\hline \multirow[t]{2}{*}{ Human capital indicators } & \multicolumn{2}{|c|}{$\begin{array}{l}\text { Before MAFISA } \\
\text { support }\end{array}$} & \multicolumn{2}{|c|}{$\begin{array}{l}\text { After MAFISA } \\
\text { support }\end{array}$} \\
\hline & High & Low & High & Low \\
\hline Financial management skills & $13(4.8)$ & 260(95.2) & 260(95.2) & $13(4.8)$ \\
\hline Marketing management skills & $11(4.0)$ & 262(96.0) & 257(94.1) & 16(5.9) \\
\hline Extension service & $35(12.8)$ & 238(87.2) & 253(92.7) & $20(7.3)$ \\
\hline Skills training & $12(4.4)$ & 261(95.6) & & $23(8.4)$ \\
\hline Technical training & $12(4.4)$ & 261(95.6) & 242(88.6) & $31(11.4)$ \\
\hline Auctioning skills & $18(6.6)$ & 255(93.4) & 245(89.7) & $28(10.3)$ \\
\hline Project management skills & $10(3.7)$ & 263(96.3) & 250(91.6) & 23(8.4) \\
\hline $\begin{array}{l}\text { Employment opportunities } \\
\text { created }\end{array}$ & $9(3.3)$ & 264(96.7) & 263(96.3) & $10(3.7)$ \\
\hline Veld management skills & $9(3.3)$ & 264(96.7) & 215(78.8) & $58(21.2)$ \\
\hline Grazing management skills & $7(2.6)$ & 266(97.4) & 213(78.0) & $60(22.0)$ \\
\hline Grain management skills & $6(2.2)$ & 267(97.8) & $40(14.7)$ & 233(85.3) \\
\hline Vegetable management skills & $4(1.5)$ & 269(98.5) & $46(16.8)$ & $227(83.2)$ \\
\hline Poultry management skills & $7(2.6)$ & 266(97.4) & 219(80.2) & $54(19.8)$ \\
\hline Piggery management skills & $21(7.7)$ & 268(98.2) & 215(78.8) & $58(21.2)$ \\
\hline Training on record-keeping & $14(5.1)$ & 259(94.9) & 261(95.6) & $12(4.4)$ \\
\hline Livestock management skills & $16(5.9)$ & 257(94.1) & $216(79.1)$ & $57(20.9)$ \\
\hline $\begin{array}{l}\text { Skills on the treatment of } \\
\text { diseases }\end{array}$ & $21(7.7)$ & 252(92.3) & $214(78.4)$ & $59(21.6)$ \\
\hline Skills in soil management & $10(3.7)$ & 263(96.3) & 49(17.9) & $224(82.1)$ \\
\hline Water management skills & $25(9.2)$ & 248(90.8) & 253(92.7) & $20(7.3)$ \\
\hline Management training skills & $17(6.2)$ & 256(93.8) & 249(91.2) & $24(8.8)$ \\
\hline $\begin{array}{l}\text { Price determination training } \\
\text { skills }\end{array}$ & $31(11.4)$ & $242(88.6)$ & 259(94.9) & $14(5.1)$ \\
\hline $\begin{array}{l}\text { Resources management } \\
\text { training skills }\end{array}$ & $17(6.2)$ & 256(93.8) & 260(95.2) & $13(4.8)$ \\
\hline Equipment handling skills & $40(14.7)$ & 233(85.3) & 255(93.4) & 18(6.6) \\
\hline Crop protection skills & $12(4.4)$ & 261(95.6) & $41(15.0)$ & $232(85.0)$ \\
\hline
\end{tabular}

Figures in parentheses are percentages

income generated $(Z=-16.156)$; personal savings $(Z=-16.032)$; business investments $(Z=-16.063)$; loss of income $(Z=-15.297)$; level of indebtedness $(Z=-15.876)$; personal loans taken $(Z=-15.100)$; and loan shark services $(Z=-15.621)$. The $p$ values of the results were less than 0.05 . This result implies that MAFISA support was able to trigger changes in the indicators of the "livelihoods of beneficiaries" regarding access to MAFISA's financial services. The number of positive ranks for each of the indicators lends credence to the significance difference as shown by the $Z$ values. The study by [41] revealed that farmers' access to livelihood capitals such as financial capital improves their farming management abilities and result in their agricultural entrepreneurial capabilities being boosted.
Mumuni and Oladele [41] asserted that financial capital in agriculture is converted and generated into cash for household expenses from farmers' product and is also used for making savings to cater for their needs during bad seasons and challenging times.

The results of physical capital of the project on "before and after" of the project are presented in Table 2, and these results show the differences in the indicators on physical capital before and after MAFISA support using the Wilcoxon signed-rank test. From 15 physical indicators tested, 13 showed significant difference while two did not. These indicators are: storage facility $(Z=-15.300)$; residential property owned $(Z=-15.067)$; irrigation infrastructure $(Z=-5.935)$; water equipment ( $Z=-15.685)$; breeding stock $(Z=-14.833)$; tractor $(Z=-4.959)$; tiller $(Z=-4.347)$; dipping tanks $(Z=-15.457)$; kraals $(Z=-13.191)$; availability of electricity $(Z=-15.621)$; transport $(Z=-15.493)$; and markets $(Z=-4.953)$. The $p$ values of the results were less than 0.05 . This result implies that MAFISA support could trigger changes in the indicators of livelihoods of beneficiaries. These beneficiaries acquired more assets because of the financial support they enjoyed. The number of positive ranks for each of the indicators lends credence to the significant difference as shown by the $Z$ values. Wilcoxon signed-rank test compares two related samples such as "before and after" with the same sample population for ranking. Mumuni and Oladele [41] went further to highlight that the test applies to two-sample designs that involve repeated measures and matched pairs before and after the impact on their livelihoods. Nxumalo and Antwi [42] assert that a Wilcoxon signed-rank sum test is a nonparametric version of a paired-samples $t$ test and can be used if research does not want to assume that the difference between two variables is interval or normally distributed.

Table 3 shows the result of the differences in the indicators on social capital before and after MAFISA support using the Wilcoxon signed-rank test. This was because indicators on social capital were measured on ordinal scale of high and low for before and after MAFISA support to beneficiaries, respectively. All the seven social indicators tested showed significant difference. These are: access farmers' groups $(Z=-15.875)$; network with government $(Z=-15.811)$; network with the private sector $(Z=-15.363)$; network with trade unions $(Z=-15.621)$; network with farmers' associations $(Z=-15.811)$; network with financial institutions $(Z=-15.843)$; and network with other farmers $(Z=-15.428)$. The $p$ values of the results were less than 0.05 . This result implies that MAFISA support could trigger changes in the indicators 
Table 2 Wilcoxon signed-rank test for financial capital $(n=280)$

\begin{tabular}{|c|c|c|c|c|c|c|}
\hline & Ranks & $N$ & Mean rank & Sum of ranks & $Z$ & Asymp. sig (2-tailed) \\
\hline \multicolumn{7}{|l|}{ Financial capital indicators } \\
\hline \multirow[t]{3}{*}{ Banks } & Negative ranks & & .00 & .00 & & \\
\hline & Positive ranks & 244 & 122.50 & $29,890.00$ & -15.56 & .000 \\
\hline & Ties & 29 & & & & \\
\hline \multirow[t]{3}{*}{ Money lenders } & Negative ranks & 12 & 13.50 & 62.00 & & \\
\hline & Positive ranks & 14 & 13.50 & 189.00 & -.196 & .845 \\
\hline & Ties & 247 & & & & \\
\hline \multirow[t]{3}{*}{ Cooperatives } & Negative ranks & 5 & 75.00 & 3.75 .00 & & \\
\hline & Positive ranks & 144 & 122 & $10,800.00$ & -11.30 & .000 \\
\hline & Ties & 124 & & & & \\
\hline \multirow[t]{3}{*}{ Relatives } & Negative ranks & 247 & 124.50 & $30,751.50$ & & \\
\hline & Positive ranks & 1 & 124.50 & 124.50 & -15.55 & .000 \\
\hline & Ties & 25 & & & & \\
\hline \multirow[t]{3}{*}{ Government subsidies } & Negative ranks & 0 & .00 & .00 & & \\
\hline & Positive ranks & 14 & 7.50 & 105.50 & .000 & .000 \\
\hline & Ties & 259 & & & & \\
\hline \multirow[t]{3}{*}{ Government grant } & Negative ranks & 9 & 9.50 & 85.50 & & .000 \\
\hline & Positive ranks & 9 & 9.50 & 85.50 & 1.000 & .000 \\
\hline & Ties & 255 & & & & .000 \\
\hline \multirow[t]{3}{*}{ Income generated } & Negative ranks & 0 & 0.00 & .00 & & \\
\hline & Positive ranks & 263 & 132.50 & $34,716.00$ & -16.15 & .000 \\
\hline & Ties & 10 & & & & \\
\hline \multirow[t]{3}{*}{ Personal savings } & Negative ranks & 1 & 132.00 & 132.00 & & \\
\hline & Positive ranks & 262 & 132.00 & $34,584.00$ & -16.03 & .000 \\
\hline & Ties & 10 & & & & \\
\hline \multirow[t]{3}{*}{ Business investments } & Negative ranks & 1 & 132.50 & 132.50 & & \\
\hline & Positive ranks & 263 & 132.50 & $34,847.50$ & -16.06 & .000 \\
\hline & Ties & 9 & & & & \\
\hline \multirow[t]{3}{*}{ Loss of income } & Negative ranks & 236 & 118.50 & $27,966.00$ & & \\
\hline & Positive ranks & 0 & .00 & .00 & -15.29 & .000 \\
\hline & Ties & 37 & & & & \\
\hline \multirow[t]{3}{*}{ Level of indebtedness } & Negative ranks & 257 & 129.50 & $33,281.50$ & & \\
\hline & Positive ranks & 1 & 129.50 & 129.50 & -15.87 & .000 \\
\hline & Ties & 15 & & & & \\
\hline \multirow[t]{3}{*}{ Personal loans taken } & Negative ranks & 230 & 115.50 & $26,565.00$ & & \\
\hline & Positive ranks & 0 & .00 & .00 & -15.10 & .000 \\
\hline & Ties & 43 & & & & \\
\hline \multirow[t]{3}{*}{ Loan sharks'services } & Negative ranks & 246 & 123.50 & $30,381.00$ & & \\
\hline & Positive ranks & 0 & .00 & .00 & -15.62 & .000 \\
\hline & Ties & 27 & & & & \\
\hline
\end{tabular}

of livelihoods of beneficiaries by creating networks with other institutions and people. The number of positive ranks for each of the indicators lends credence to the significant difference as shown by the $Z$ values.
Table 4 shows the result of the differences in the indicators on human capital before and after MAFISA support using the Wilcoxon signed-rank test. This was because indicators on human capital were measured on ordinal 
Table 3 Wilcoxon signed-rank test for physical capital $(n=280)$

\begin{tabular}{|c|c|c|c|c|c|c|}
\hline & Ranks & $N$ & Mean rank & Sum of ranks & $Z$ & Asymp. sig (2-tailed) \\
\hline \multirow[t]{3}{*}{ Storage facility accessibility } & Negative ranks & 2 & 122.50 & 245 & & \\
\hline & Positive ranks & 242 & 122.50 & $29,645.00$ & -15.30 & .000 \\
\hline & Ties & 29 & & & & \\
\hline \multirow[t]{3}{*}{ Residential property owned } & Negative ranks & 0 & .00 & .00 & & \\
\hline & Positive ranks & 229 & 115.00 & $26,335.00$ & -15.06 & .000 \\
\hline & Ties & 44 & & & & \\
\hline \multirow[t]{3}{*}{ Irrigation infrastructure } & Negative ranks & 1 & 21.00 & 21.00 & & \\
\hline & Positive ranks & 40 & 21 & 840.00 & -5.93 & .000 \\
\hline & Ties & 232 & & & & \\
\hline \multirow[t]{3}{*}{ Road infrastructure } & Negative ranks & 18 & 19.50 & 351.00 & & \\
\hline & Positive ranks & 20 & 19.50 & 390.00 & -.162 & .871 \\
\hline & Ties & 235 & & & & \\
\hline \multirow[t]{3}{*}{ Water equipment } & Negative ranks & 0 & .00 & .00 & & \\
\hline & Positive ranks & 248 & 124.50 & $30,876.00$ & -15.68 & .000 \\
\hline & Ties & 25 & & & & \\
\hline \multirow[t]{3}{*}{ Breeding stock } & Negative ranks & 0 & .00 & .00 & & \\
\hline & Positive ranks & 222 & 111.50 & $24,753.00$ & -14.83 & .000 \\
\hline & Ties & 255 & & & & \\
\hline \multirow[t]{3}{*}{ Combine harvester } & Negative ranks & 0 & .00 & .00 & & \\
\hline & Positive ranks & 3 & 2.00 & 6.00 & 0.155 & .250 \\
\hline & Ties & 270 & & & & \\
\hline \multirow[t]{3}{*}{ Tractor } & Negative ranks & 6 & 24.00 & 144.00 & & \\
\hline & Positive ranks & 41 & 24.00 & 984.00 & -4.95 & .000 \\
\hline & Ties & 226 & & & & \\
\hline \multirow[t]{3}{*}{ Power generator } & Negative ranks & 2 & 6.50 & 13.00 & & \\
\hline & Positive ranks & 10 & 6.50 & 65.00 & 2.14 & .039 \\
\hline & Ties & 26 & & & & \\
\hline \multirow[t]{3}{*}{ Tiller } & Negative ranks & 2 & 14.50 & 29.00 & & \\
\hline & Positive ranks & 26 & 14.50 & 377.00 & -4.347 & .000 \\
\hline & Ties & 245 & & & & \\
\hline \multirow[t]{3}{*}{ Dipping tanks } & Negative ranks & 0 & .00 & .00 & & \\
\hline & Positive ranks & 21 & 106.00 & $22,366.00$ & -15.45 & .000 \\
\hline & Ties & 62 & & & & \\
\hline \multirow[t]{3}{*}{ Kraals } & Negative ranks & 0 & .00 & .00 & & \\
\hline & Positive ranks & 176 & 88.50 & $15,576.00$ & -13.19 & .000 \\
\hline & Ties & 97 & & & & \\
\hline \multirow[t]{3}{*}{ Electricity availability } & Negative ranks & 0 & .00 & .00 & & \\
\hline & Positive ranks & 246 & 123.50 & $30,381.00$ & -15.62 & .000 \\
\hline & Ties & 27 & & & & \\
\hline \multirow[t]{3}{*}{ Transport } & Negative ranks & 1 & 123.50 & 123.50 & & \\
\hline & Positive ranks & 245 & 123.50 & $30,257.50$ & -15.49 & .000 \\
\hline & Ties & 27 & & & & \\
\hline \multirow[t]{3}{*}{ Markets } & Negative ranks & 11 & 31.50 & 346.50 & & \\
\hline & Positive ranks & 51 & 31.50 & 1606.50 & -4.95 & .000 \\
\hline & Ties & 211 & & & & \\
\hline
\end{tabular}


Table 4 Wilcoxon signed-rank test for social capital $(n=280)$

\begin{tabular}{|c|c|c|c|c|c|c|}
\hline & Ranks & $N$ & Mean rank & Sum of ranks & $Z$ & Asymp. sig (2-tailed) \\
\hline \multirow[t]{3}{*}{ Farmers'groups } & Negative ranks & 0 & .00 & .00 & & \\
\hline & Positive ranks & 252 & 126.50 & $31,878.00$ & -15.875 & .000 \\
\hline & Ties & 21 & & & & \\
\hline \multirow[t]{3}{*}{ Network with government } & Negative ranks & 0 & .00 & .00 & & \\
\hline & Positive ranks & 250 & 125.50 & $31,375.00$ & -15.811 & .000 \\
\hline & Ties & 23 & & & & \\
\hline \multirow[t]{3}{*}{ Network with the private sector } & Negative ranks & 1 & 120.50 & 120.50 & & \\
\hline & Positive ranks & 239 & 120.50 & $28,799.50$ & -15.363 & .000 \\
\hline & Ties & 33 & & & & \\
\hline \multirow[t]{3}{*}{ Network with trade unions } & Negative ranks & 1 & 124.50 & 124.50 .00 & & \\
\hline & Positive ranks & 247 & 124.50 & $30,751.50$ & -15.621 & .000 \\
\hline & Ties & 25 & & & & \\
\hline \multirow[t]{3}{*}{ Network with farmers' associations } & Negative ranks & 0 & .00 & .00 & & \\
\hline & Positive ranks & 250 & 125.50 & $31,375.00$ & -15.811 & .000 \\
\hline & Ties & 23 & & & & \\
\hline \multirow[t]{3}{*}{ Network with financial institutions } & Negative ranks & 0 & .00 & .00 & & \\
\hline & Positive ranks & 251 & 126.00 & $31,626.00$ & -15.843 & .000 \\
\hline & Ties & 22 & & & & \\
\hline \multirow[t]{3}{*}{ Network with other farmers } & Negative ranks & 1 & 121.50 & 121.50 & & \\
\hline & Positive ranks & 241 & 121.50 & $29,281.50$ & -15.428 & .000 \\
\hline & Ties & 31 & & & & \\
\hline
\end{tabular}

scale of high and low for before and after MAFISA support to beneficiaries, respectively. All the 24 indicators on human capital tested showed significant difference. These skills are as follows: financial management $(Z=-15.653)$; marketing management $(Z=-15.621)$; extension services $(Z=-14.437)$; skills training $(Z=-15.427)$; technical training $(Z=-14.972)$; auctioning $(Z=-15.001)$; project management $(Z=-15.492)$; employment opportunities created $(Z=-15.937)$; veld management $(Z=-14.353)$; grazing management $(Z=-14.353)$; grain management $(Z=-5.831)$; vegetable management $(Z=-6.481)$; poultry management $(Z=-14.560)$; piggery management $(Z=-14.491)$; training on record-keeping ( $Z=-15.591$ ); livestock management $(Z=-14.072)$; treatment of diseases $(Z=-13.821)$; soil management $(Z=-5.814)$; water management $(Z=-15.034)$; management training $(Z=-15.232)$; price determination training $(Z=-14.969)$; resources management training $(Z=-15.525)$; handling of equipment $(Z=-14.397)$; and crop protection $(Z=-5.048)$. The $p$ values of the results were less than 0.05 . This result implies that MAFISA support could improve the skills of beneficiaries. The number of positive ranks for each of the indicators lends credence to the significant difference as shown by the $Z$ values. Nxumalo and Antwi [42] argued human capital's emphasis on empowerment through both formal and informal education. According to [42], the Wilcoxon signed-rank test is robust and highly efficient, especially for moderate- to heavy-tailed underlying distributions.

Table 5 shows the result of the differences in the indicators on natural capital before and after MAFISA support using the Wilcoxon signed-rank test. This was because indicators on natural capital were measured on ordinal scale of high and low for before and after MAFISA support to beneficiaries, respectively. From 11 natural indicators tested, 10 showed significant difference while one did not. These are: size of land $(Z=-15.264)$; amount of water used $(Z=-15.236)$; quality of water $(Z=-14.905)$; size of land cultivated $(Z=-5.691)$; ownership of land $(Z=-2.324)$; natural pasture $(Z=-13.194)$; types of pasture $(Z=-13.892)$; size of pasture $(Z=-14.697)$; labour employed $(Z=-15.591)$; and natural water sources $(Z=-14.900)$. The $p$ values of the results were less than 0.05. This result implies that MAFISA support could 
Table 5 Wilcoxon signed-rank test for human capital $(n=280)$

\begin{tabular}{|c|c|c|c|c|c|c|}
\hline & Ranks & $N$ & Mean rank & Sum of ranks & $Z$ & Asymp. sig (2-tailed) \\
\hline \multirow[t]{3}{*}{ Financial management } & Negative ranks & 1 & 125.00 & 125.00 & & \\
\hline & Positive ranks & 248 & 125.00 & $31,000.00$ & -15.65 & .000 \\
\hline & Ties & 24 & & & & \\
\hline \multirow[t]{3}{*}{ Marketing management } & Negative ranks & 1 & 124.50 & 124.50 & & \\
\hline & Positive ranks & 247 & 124.50 & $30,751.50$ & -15.62 & .000 \\
\hline & Ties & 25 & & & & \\
\hline \multirow[t]{3}{*}{ Extension services } & Negative ranks & 5 & 114.50 & 572.50 & & \\
\hline & Positive ranks & 223 & 114.50 & $25,533.50$ & -14.43 & .000 \\
\hline & Ties & 45 & & & & \\
\hline \multirow[t]{3}{*}{ Skills training } & Negative ranks & 0 & .00 & .00 & & \\
\hline & Positive ranks & 238 & 119.50 & $28,441.00$ & -15.42 & .000 \\
\hline & Ties & 35 & & & & \\
\hline \multirow[t]{3}{*}{ Technical training } & Negative ranks & 3 & 118.50 & 355.50 & & \\
\hline & Positive ranks & 233 & 118.50 & $27,610.50$ & -14.97 & .000 \\
\hline & Ties & 37 & & & & \\
\hline \multirow[t]{3}{*}{ Auctioning skills } & Negative ranks & 1 & 115.00 & 115.00 & & \\
\hline & Positive ranks & 228 & 115.00 & $26,220.00$ & -15.00 & .000 \\
\hline & Ties & 44 & & & & \\
\hline \multirow[t]{4}{*}{ Project management } & Negative ranks & 0 & .00 & .00 & & \\
\hline & Positive ranks & 240 & 120.50 & $28,920.00$ & -15.49 & .000 \\
\hline & Ties & 33 & & & & \\
\hline & Total & 273 & & & & \\
\hline \multirow[t]{3}{*}{ Employment opportunities created } & Negative ranks & 0 & .00 & .00 & & \\
\hline & Positive ranks & 254 & 127.50 & $32,385.00$ & -15.93 & .000 \\
\hline & Ties & 19 & & & & \\
\hline \multirow[t]{3}{*}{ Veld management } & Negative ranks & 0 & .00 & .00 & & \\
\hline & Positive ranks & 206 & 103.50 & $21,321.00$ & -14.35 & .000 \\
\hline & Ties & 67 & & & & \\
\hline \multirow[t]{3}{*}{ Grazing management } & Negative ranks & 0 & .00 & .00 & & \\
\hline & Positive ranks & 206 & 103.50 & $21,321.00$ & -14.35 & .000 \\
\hline & Ties & 67 & & & & \\
\hline \multirow[t]{3}{*}{ Grain management } & Negative ranks & 0 & .00 & .00 & & \\
\hline & Positive ranks & 34 & 17.50 & 595.00 & -5.83 & .000 \\
\hline & Ties & 239 & & & & \\
\hline \multirow[t]{3}{*}{ Vegetable management } & Negative ranks & 0 & 21.50 & 903.00 & & \\
\hline & Positive ranks & 42 & 21.50 & 903.00 & -6.48 & .000 \\
\hline & Ties & 231 & & & & \\
\hline \multirow[t]{3}{*}{ Poultry management } & Negative ranks & 0 & .00 & .00 & & \\
\hline & Positive ranks & 212 & 106.50 & $22,578.00$ & -14.56 & .000 \\
\hline & Ties & 61 & & & & \\
\hline \multirow[t]{3}{*}{ Piggery management } & Negative ranks & 0 & .00 & .00 & & \\
\hline & Positive ranks & 210 & 105.50 & $22,155.00$ & -14.49 & .000 \\
\hline & Ties & 63 & & & & \\
\hline \multirow[t]{3}{*}{ Training on record-keeping } & Negative ranks & 2 & 126.00 & 252.00 & & \\
\hline & Positive ranks & 249 & 126.00 & $31,374.00$ & -15.59 & .000 \\
\hline & Ties & 22 & & & & \\
\hline \multirow[t]{3}{*}{ Livestock management skills } & Negative ranks & 2 & 101.50 & 101.50 & & \\
\hline & Positive ranks & 201 & 101.50 & $20,401.50$ & -14.07 & .000 \\
\hline & Ties & 71 & & & & \\
\hline
\end{tabular}


Table 5 continued

\begin{tabular}{|c|c|c|c|c|c|c|}
\hline & Ranks & $N$ & Mean rank & Sum of ranks & $z$ & Asymp. sig (2-tailed) \\
\hline \multirow[t]{3}{*}{ Treatment of diseases } & Negative ranks & 1 & 98.00 & 98.00 & & \\
\hline & Positive ranks & 194 & 98.00 & $19,012.00$ & -13.82 & .000 \\
\hline & Ties & 78 & & & & \\
\hline \multirow[t]{3}{*}{ Soil management } & Negative ranks & 3 & 23.00 & 69.00 & & \\
\hline & Positive ranks & 42 & 23.00 & 966.00 & -5.81 & .000 \\
\hline & Ties & 228 & & & & \\
\hline \multirow[t]{3}{*}{ Water management } & Negative ranks & 1 & 115.50 & 115.50 & & \\
\hline & Positive ranks & 229 & 115.50 & $26,449.50$ & -15.03 & .000 \\
\hline & Ties & 43 & & & & \\
\hline \multirow[t]{3}{*}{ Management training } & Negative ranks & 0 & .00 & .00 & & \\
\hline & Positive ranks & 232 & 116.50 & $27,028.00$ & -15.23 & .000 \\
\hline & Ties & 41 & & & & \\
\hline \multirow[t]{3}{*}{ Price determination training } & Negative ranks & 2 & 116.50 & 233.00 & & \\
\hline & Positive ranks & 230 & 116.50 & $26,795.00$ & -14.96 & .000 \\
\hline & Ties & 41 & & & & \\
\hline \multirow[t]{3}{*}{ Resources management training } & Negative ranks & 1 & 123.00 & 123.00 & & \\
\hline & Positive ranks & 244 & 123.00 & $30,012.00$ & -15.52 & .000 \\
\hline & Ties & 28 & & & & \\
\hline \multirow[t]{3}{*}{ Equipment handling } & Negative ranks & 4 & 112.00 & 448.00 & & \\
\hline & Positive ranks & 219 & 112.00 & $24,528.00$ & -14.39 & .000 \\
\hline & Ties & 50 & & & & \\
\hline \multirow[t]{3}{*}{ Crop protection } & Negative ranks & 2 & 17.00 & 34.00 & & \\
\hline & Positive ranks & 31 & 17.00 & 527.00 & -5.048 & .000 \\
\hline & Ties & 240 & & & & \\
\hline
\end{tabular}

trigger changes in the indicators of livelihoods of beneficiaries. The number of positive ranks for each of the indicators lends credence to the significant difference as shown by the $Z$ values (Table 6).

\section{Conclusions}

The findings in this paper are a contribution to the literature on the effect of microfinance on livelihood assets of beneficiaries. Many researches have indicated that microfinance facilities have improved beneficiaries' access to socio-economic facilities such as health, nutrition and education through increased incomes, while other contested the propagated positive impacts of microfinance and claim that microfinance does not reach the poor and even if it does it rather destroys their resourcefulness because of repayment difficulties which inhibits acquisition of vital resources. This study on effect of Micro-Agricultural Financial Institutions of South Africa on livelihood capital of beneficiaries in North West Province South Africa concludes that access to microfinance leads to significant changes in financial, social, natural, human, physical and social livelihood assets after MAFISA support. The proportion of access and ownership of livelihood assets increased for most of the indicators of the assets by at least ninety per cent after MAFISA support. Statistical significant differences confirmed the changes in the proportion of beneficiaries before and after MAFISA support such as access to financial capital from banks improved substantially and cooperatives, networking with others, network with government and network with the private sector as well as increasing their skills and competencies as well as their physical asset accumulation. The findings of this study imply that microfinance can lead to acquisitions and accumulation of important indicators of the five sustainable livelihood capital in order to lead to sustainable 
Table 6 Wilcoxon signed-rank test for natural capital $(n=280)$

\begin{tabular}{|c|c|c|c|c|c|c|}
\hline & Ranks & $N$ & Mean rank & Sum of ranks & $Z$ & Asymp. sig (2-tailed) \\
\hline \multirow[t]{3}{*}{ Size of land } & Negative ranks & 0 & .00 & .00 & & \\
\hline & Positive ranks & 233 & 117.00 & $27,261.00$ & -15.26 & .000 \\
\hline & Ties & 40 & & & & \\
\hline \multirow[t]{3}{*}{ Amount of water used } & Negative Ranks & 3 & 122.50 & 367.50 & & \\
\hline & Positive ranks & 241 & 125.50 & $29,522.50$ & -15.23 & .000 \\
\hline & Ties & 29 & & & & \\
\hline \multirow[t]{3}{*}{ Quality of water } & Negative ranks & 3 & 117.50 & 352.50 & & \\
\hline & Positive ranks & 231 & 117.50 & $22,142.50$ & -14.90 & .000 \\
\hline & Ties & 39 & & & & \\
\hline \multirow[t]{3}{*}{ Size of cultivated land } & Negative ranks & 0 & .00 & .00 & & \\
\hline & Positive ranks & 35 & 18.00 & 630.00 & -5.691 & .000 \\
\hline & Ties & 238 & & & & \\
\hline \multirow[t]{3}{*}{ Ownership of land } & Negative ranks & 3 & 8.00 & 24.00 & & \\
\hline & Positive ranks & 12 & 8.00 & 96.00 & -2.32 & .020 \\
\hline & Ties & 258 & & & & \\
\hline \multirow[t]{3}{*}{ Natural pasture } & Negative ranks & 2 & 91.50 & 183.00 & & \\
\hline & Positive ranks & 180 & 91.50 & $16,470.00$ & -13.19 & .000 \\
\hline & Ties & 91 & & & & \\
\hline \multirow[t]{3}{*}{ Types of pasture } & Negative ranks & 0 & .00 & .00 & & \\
\hline & Positive ranks & 193 & 97.00 & $18,721.00$ & -13.89 & .000 \\
\hline & Ties & 80 & & & & \\
\hline \multirow[t]{3}{*}{ Size of pasture } & Negative ranks & 0 & .00 & .00 & & \\
\hline & Positive ranks & 216 & 108.50 & $23,436.00$ & -14.69 & .000 \\
\hline & Ties & 57 & & & & \\
\hline \multirow[t]{3}{*}{ Labour employed } & Negative ranks & 2 & 126.00 & 252.00 & & \\
\hline & Positive ranks & 249 & 126.00 & $31,374.00$ & -15.59 & .000 \\
\hline & Ties & 22 & & & & \\
\hline \multirow[t]{3}{*}{ Sources of natural water } & Negative ranks & 1 & & & & \\
\hline & Positive ranks & 225 & & & -14.90 & .000 \\
\hline & Ties & 47 & & & & \\
\hline \multirow[t]{3}{*}{ Diversity of water sources } & Negative ranks & 5 & 126.00 & 630.00 & & \\
\hline & Positive ranks & 246 & 126.00 & $30,996.00$ & -15.21 & .000 \\
\hline & Ties & 22 & & & & \\
\hline
\end{tabular}

outcomes livelihoods. It also implies that proper targeting of beneficiaries will lead to improved livelihoods through microfinance.

\section{Abbreviations}

MAFISA: Micro-Agricultural Financial Institutions of South Africa.

\section{Authors' contributions}

WL designed the data collection instruments and gathered the data and analysis and write up. OOI supervised the design, the entire data collection process and provided guidance, corrections and supervision to the entire research. Both authors read and approved the final manuscript.

\section{Acknowledgements}

The authors will like to thank the Land Bank of South Africa and North-West University, Mafikeng Campus, Mmabatho, South Africa.

\section{Competing interests}

We, the authors declare that there are no competing interests.

Availability of supporting data

The questionnaire and reports on the questionnaire used for data collection in this survey are now under archive and being kept.

\section{Consent for publication}

The two authors agreed to the publication of this manuscript from the Ph.D. thesis that was submitted by WL and supervised by OOI.

\section{Ethical approval and consent to participate}

The Ethics committee of the Faculty of Agriculture, Science and Technology, North-West University, Mafikeng Campus, Mmabatho, South Africa, approved the study and beneficiaries of the microfinance who acted as respondents in the study gave voluntary consent to participate in the study.

Funding

The authors will like to thank the Land Bank of South Africa and North-West University, Mafikeng Campus, Mmabatho, South Africa. 


\section{Publisher's Note}

Springer Nature remains neutral with regard to jurisdictional claims in published maps and institutional affiliations.

Received: 18 November 2016 Accepted: 10 May 2017 Published online: 01 September 2017

\section{References}

1. DAFF. Emerging Farmer Support Services: MAFISA. 2016. http://www. agrisa.co.za/wp-content/uploads/2016/02/Emerging-Farmer-SupportServices.pdf. Accessed Oct 2016.

2. Goodwin NR. Five kinds of capital: useful concepts for sustainable development. Global Development and Environment Institute. Working paper no. 03-07. 2003. http://www.ase.tufts.edu/gdae/publications/working_papers/03-07sustainabledevelopment.PDF.

3. Kantor P, Andersen E, Sim A. Microcredit, informal credit and rural livelihoods: a village case study in Bamyan Province. Afghanistan research and evaluation unit. 2008. http://www.microfinancegateway.org/library/ microcredit-informal-credit-and-rural-livelihoods-village-case-studybamyan-province.

4. Handa S, Park M, Darko RO, Osi-Akoto I, Davis B, Diadone S. Livelihood empowerment against poverty program impact evaluation. Carolina Population Center University of North Carolina at Chapel Hill. 2013. http://www.unicef.org/ghana/gh_resources_LEAP_Quant_impact_evaluation_FINAL_OCT_2013.pdf.

5. Fatoki OO. The impact of human, social and financial capital on the performance of small and medium-sized enterprises (SMEs) in South Africa. J Soc Sci. 2011;29(3):193-204.

6. Ferka A. The impact of microfinance on the livelihoods of women in rural communities: a case study of Jaman South District, Ghana. Thesis submitted to the Institute of Distance Learning. 2011.

7. Thennakoon S. Rural livelihood strategies and the five capitals: a comparative study in selected villages of Sri Lanka. In: Proceedings of the 18th European conference on modern South Asian Studies. Lund, Sweden, July 6-9, paper 5. 2004

8. Kollmair M, Gamper S. The sustainable livelihoods approach. Input paper for the integrated training course of NCCR North-South Aeschiried, Switzerland Development Study Group, University of Zurich (IP6). 2002. http://www. nccr-pakistan.org/publications_pdf/General/SLA Gamper_Kollmair.pdf.

9. Bhuiyan AB. Microcredit and sustainable livelihood: an empirical study of Islamic and conventional credit on the development of human capital of the borrowers in Bangladesh. J Econ Coop Dev. 2013;34(3):101-28.

10. Su F, Shang H. Relationship analysis between livelihood assets and livelihood strategies: a Heihe River Basin example. Sci Cold Arid Reg. 2012:4(3):0265-74. doi:10.3724/SP.J.1226.2012.00265.

11. Teekens A. Entrepreneurship and microfinance: a framework for impact evaluation. Master thesis in Universiteit van Amsterdam. 2009. http:// dare.uva.nl/cgi/arno/show.cgi?fid=143493. Accessed Oct 2016.

12. Moruf $O$. Evaluation of the Nigerian Microfinance banks credit administration on small and medium scale enterprises operation. Int Rev Manag Bus Res. 2013;2:505-17.

13. Quach MH, Mullineux AW, Murinde V. Access to credit and household poverty reduction in rural Vietnam: a cross sectional study. 2005. http://www.grips.ac.jp/vietnam/VDFTokyo/Doc/1stConf18Jun05/OPP01QuachPPR.pdf.

14. Sebstad J, Chen G. Overview of studies on the impact of microenterprise credit. Management systems international. June 1996 assessing the impact of microenterprise services (AIMS). 1996. http://pdf.usaid.gov/ pdf docs/Pnabz074.pdf.

15. Mula G, Sarker SC. Impact of microfinance on women empowerment: an economic analysis from eastern India. Afr J Agric Res. 2013;8(45):5673-84.

16. Kgowedi MJ. Informal financial services in a peri-urban setting. A case study of Moletji district in the Northern Province. Master thesis University of Pretoria. 2002.

17. Lohlein $D$, Wehrheim $P$. The role of credit co-operatives in rural Russia. GLOROS policy paper. German Institute for Economic Research. 2003. http://citeseerx.ist.psu.edu/viewdoc/download?doi=10.1.1.581.6913\&rep $=$ rep $1 \&$ type $=$ pdf.
18. Wrenn E (2007). Perceptions of the impact of microfinance on livelihood security. Research and perspectives on development practice. 2007. http://kimmagedsc.ie/wp-content/uploads/2013/10/eoinwrennsmallpdf. com_.pdf.

19. Shier R. Statistics: 2.2 the Wilcoxon Signed Rank Sum Test. Mathematics learning support centre. 2004. http://www.statstutor.ac.uk/resources/ uploaded/wilcoxonsignedranktest.pdf. Retrieved 28 Feb 2016.

20. Lowry R. Concepts and applications of inferential statistics. 2011. http:// vassarstats.net/textbook/ch12a.html. Retrieved 28 Feb 2016.

21. Crepon B, Devoto F, Duflo E, Pariente W. Estimating the impact of microcredit on those who take it up: evidence from a randomized experiment in Morocco. 2014. http://economics.mit.edu/files/6659.

22. Duvendack M, Palmer-Jones R. High noon for microfinance impact evaluations: re-investigating the evidence from Bangladesh. J Dev Stud. 2012;48(12):1864-80. doi:10.1080/00220388.2011.646989.

23. Hettmansperger TP, Mottonen J, Oja H. Affine invariant multivariate onesample signed-rank tests. J Am Stat Assoc. 1997;92:1591-600. doi:10.1080 /01621459.1997.10473681.

24. Murali KS. Microfinance, social capital and natural resource management systems: conceptual issues and empirical evidences. Int J Agric Resour Gov Ecol. 2006;5(4):327-37.

25. Diro BA, Regasa DG. Impact of micro credit on the livelihood of borrowers: evidence from Mekelle City, Ethiopia. J Res Econ Int Financ. 2014;3(1):25-32. doi:10.14303/jrief.2014.0112014.

26. Khatun F, Hasan M. Social capital in microfinance: a critical investigation of Bangladesh. J Emerg Trends Econ Manag Sci. 2006;6(5):315-23.

27. World Bank (WB). Bangladesh data profile. World development indicators database. 2006

28. Ameen F, Sulaiman M. Social capital and economic wellbeing. CFPR working paper series no. 15, Research and Evaluation Division, BRAC. 2006.

29. Molyneux M. Gender and the silences of social capital: lessons from Latin America. Dev Change. 2002;3(2):167-88.

30. Makina D, Malobola LM. Impact assessment of microfinance programmes, including lessons from Khula enterprise finance. Dev Bank S Afr. 2004;21(5):799-814

31. Krueger A, Lindahl M. Education for growth: why and for whom? NBER working paper no. W7591. Cambridge: National Bureau of Economic Research. 2000

32. Enisan AA, Oluwafemi OI. Impact of microfinance on poverty alleviation in Ondo State, Nigeria. Aust J Bus Manag Res. 2012;2(9):31-7.

33. Gubert F, Roubaud F. The impact of microfinance loans on small informal enterprises in Madagascar. A panel data analysis. 2011. http://www.iss. nl/fileadmin/ASSETS/iss/Documents/Research_and_projects/Unlocking_potential_Microfinance.pdf.

34. Anderson LC, Locker L, Nugent R. Microcredit, social capital and common pool resources. World Dev. 2002;30(1):95-105.

35. Ramakrishnappa $V$, Rao RJ. Emerging micro-finance issues in dairy development: case studies from Karnataka. Int J Agric Resour Gov Ecol. 2005;5:413-27.

36. Adjei JK, Arun T, Hossain F. The role of microfinance in asset-building and poverty reduction: the case of Sinapi Aba Trust of Ghana. BWPI working paper 87 March 2009 Brooks World Poverty Institute. 2009.

37. Odell K. Measuring the impact of microfinance: taking another look Grameen Foundation, Washington, DC. 2010. http://www.grameenfoundation.org/resource/measuring-impact-microfinance.

38. Planet Finance. Egypt country overview. 13 rue Dieumegard 93400 SaintOuen Paris, France. 2008.

39. Gebru B, Paul I. Role of microfinance in alleviating urban poverty in Ethiopia. J Sustain Dev Afr. 2011;13(6):165-80.

40. Antoh EF, Mensah JV, Edusah SE. The effect of microfinance on human capital development in Ghana: the case of Sinapi Aba trust microfinance beneficiaries in Ashanti Region. Int J Soc Sci Hum Invent. 2015;2(08):1498-514. doi:10.18535/ijsshi/v2i8.03.

41. Mumuni E, Oladele Ol. Access to livelihood capitals and propensity for entrepreneurship amongst rice farmers in Ghana. Agric Food Secur. 2016:5:1. doi:10.1186/s40066-015-0049-x.

42. Nxumalo KKS, Antwi MA. Impact of proactive land acquisition strategy on physical capital of beneficiaries in Dr. Kenneth Kaunda District, South Africa. J Hum Ecol. 2013;44(2):161-9. 